\title{
A new generation of antipsychotics: pharmacology and clinical utility of cariprazine in schizophrenia
}

This article was published in the following Dove Press journal:

Therapeutics and Clinical Risk Management

7 August 2013

Number of times this article has been viewed

\author{
Silvio Caccia \\ Roberto William Invernizzi \\ Alessandro Nobili \\ Luca Pasina \\ IRCCS-Istituto di Ricerche \\ Farmacologiche Mario Negri, \\ Milan, Italy
}

\begin{abstract}
Cariprazine is a potential antipsychotic awaiting approval from the US Food and Drug Administration. It is a dopamine $\mathrm{D}_{2}$ - and $\mathrm{D}_{3}$-receptor partial agonist, with higher affinity for $\mathrm{D}_{3}$ receptors, as opposed to the $\mathrm{D}_{2}$ antagonism of most older antipsychotic agents. Like most lipophilic antipsychotics, it undergoes extensive hepatic metabolism by cytochrome P450 (CYP), mainly the highly variable 3A4, with the formation of active metabolites. However, the parent compound - particularly its active didesmethyl derivative - is cleared very slowly, with elimination half-lives in schizophrenic patients ranging from 2-5 days for cariprazine to 2-3 weeks for didesmethyl-cariprazine. Exposure to the latter was several times that for cariprazine, although didesmethyl-cariprazine did not reach steady state within the 3 weeks of $12.5 \mathrm{mg}$ /day dosing. Preliminary information on its therapeutic role comes from press releases and a few abstracts presented at scientific meetings. In short-term controlled trials, it was more effective than placebo in reducing positive and negative symptoms of schizophrenia, with an effective dose range of 1.5-12 mg/day. Although cariprazine was associated with a higher incidence of akathisia and extrapyramidal side effects than placebo, it did not cause weight gain, metabolic abnormalities, prolactin increase, or corrected QT prolongation. Similarly, cariprazine's efficacy and tolerability for the treatment of bipolar disorder (manic/mixed and depressive episodes) was established in the dose range of 3-12 $\mathrm{mg} / \mathrm{day}$, although again no longterm data are available. Well-designed clinical trials, mainly direct "head-to-head" comparisons with other second-generation antipsychotic agents, are needed to define the therapeutic role and safety profile of cariprazine in schizophrenia and bipolar mania.
\end{abstract}

Keywords: cariprazine, antipsychotic, pharmacology, pharmacokinetics, efficacy, safety

\section{Introduction}

Schizophrenia causes positive symptoms, such as delusions and hallucinations, negative symptoms, which include lack of motivation and social withdrawal, and cognitive deficits. Antipsychotic drugs, including either first or second generation, are fundamental for the treatment of these symptoms. Unfortunately, first-generation agents (generally called typical antipsychotics) are very effective for managing the positive symptoms of schizophrenia but have relatively poor long-term efficacy for negative symptoms, mood disturbances, and cognitive deficits. They are also associated with debilitating extrapyramidal symptoms and tardive dyskinesia, thus often nullifying their therapeutic benefits. Although second-generation drugs (also called atypical antipsychotics) provide a broader range of efficacy, relieving both positive and negative symptoms with a lower risk of extrapyramidal symptoms and tardive dyskinesia, ${ }^{1-3}$ they do not really improve cognitive dysfunctions; moreover, their use may be associated with weight
Roberto W Invernizzi

IRCCS-Istituto di Ricerche

Farmacologiche Mario Negri,

Via La Masa 19, 20156 Milan, Italy

Tel +3902 390l 4556

$\mathrm{Fax}+390239001916$

Email silvio.caccia@marionegri.it;

rinvernizzi@marionegri.it 
gain, metabolic abnormalities, and cardiovascular adverse events, which may be just as problematic for the patients as the main adverse effects of first-generation drugs. ${ }^{4-6}$ Thus, new agents are still needed that combine the activity of the older drugs against the positive symptoms of schizophrenia with greater efficacy on the negative symptoms and cognitive deficits, with fewer adverse effects.

In response to these needs, several new compounds acting somewhat differently from first- and second-generation antipsychotics have been studied. ${ }^{7-11}$ These include cariprazine, which is in a late stage of clinical development for the treatment of schizophrenia as well as for bipolar disorders, and as an adjunctive treatment option for major depressive disorder. ${ }^{12,13}$ This compound is defined as a dopamine (DA) $\mathrm{D}_{3}$-preferring $\mathrm{D}_{3} / \mathrm{D}_{2}$-receptor partial agonist, unlike most typical and atypical antipsychotics, which partially or totally block striatal $\mathrm{D}_{2}$ receptors besides characteristic serotonin (5-HT) and norepinephrine subtype receptors. It is therefore more like aripiprazole, which also combines partial agonism at dopamine receptors with agonism at $5-\mathrm{HT}_{1 \mathrm{~A}} \cdot{ }^{14,15} \mathrm{An}$ application for its approval (acute indications of schizophrenia and bipolar mania/mixed episodes) by the US Food and Drug Administration (FDA) is pending.

This review summarizes the current evidence for the efficacy, tolerability, and safety of this potential new agent for schizophrenia and bipolar mania/mixed episodes. Pharmacodynamic and pharmacokinetic data relevant to the actions of cariprazine are also reviewed and compared with the pharmacological profile of older antipsychotics that are already on the market for similar indications.

Using the keywords "cariprazine", "RGH-188", "schizophrenia", and "bipolar disorder", a literature search was done, using the international databases Medline and Embase, to find all studies published before April 2013. No date or language constraints were applied. Bibliographies from published literature, clinical trial registries/databases, and websites were also considered.

\section{Pharmacodynamic and pharmacokinetic profile Pharmacodynamics}

Data in this section come from abstracts and a few full research reports and reviews ${ }^{12,13}$ on cariprazine.

Chemically, cariprazine (RGH-188; $N^{\prime}$-[trans-4-[2-[4(2,3-dichlorophenyl)-1-piperazinyl] ethyl]cyclohexyl]- $N, N$ dimethylurea) (Figure 1) belongs to a series of piperazine/ piperidine derivatives mainly targeting DA-receptor subtypes $2\left(\mathrm{D}_{2}\right)$ and $3\left(\mathrm{D}_{3}\right)$. The synthesis of these compounds

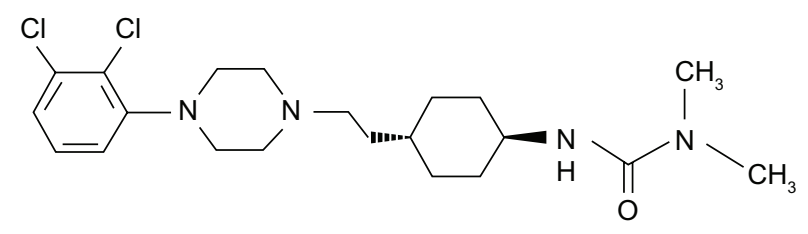

Figure I Chemical structure of cariprazine ( $N^{\prime}$-[trans-4-[2-[4-(2,3-dichlorophenyl)I-piperazinyl] ethyl]cyclohexyl]-N,N-dimethylurea).

stems from the hypothesis that besides the assumption that $\mathrm{D}_{2}$-receptor blockade is necessary for antipsychotic efficacy, $\mathrm{D}_{3}$-receptor antagonism/partial agonism might improve the cognitive deficits of schizophrenia and reduce the side effects associated with $\mathrm{D}_{2}$-receptor blockade. ${ }^{16}$ Cariprazine was selected for development because of its excellent brain entry and safety profile, with at the same time appreciable activity in tests predictive of antipsychotic efficacy. ${ }^{14}$

\section{In vitro selectivity of cariprazine}

\section{for neurotransmitter receptors}

Radioligand-binding studies in membrane preparations from cells (human embryonic kidney [HEK] 293-hD 2 and Chinese hamster ovary $[\mathrm{CHO}]-\mathrm{hD}_{3}$ ) transfected with human DAreceptor subtypes showed that cariprazine has subnanomolar affinity for $\mathrm{D}_{3^{-}}, \mathrm{D}_{2 \mathrm{~L}^{-}},(\mathrm{pKi}=10.07$ and 9.31 , respectively) and $\mathrm{D}_{2 \mathrm{~S}}$-receptor subtypes. ${ }^{15,17}$ It showed six- to tenfold-higher affinity for the human $\mathrm{D}_{3}$ than the $\mathrm{D}_{2}$ receptor. ${ }^{14,15}$ Cariprazine has lower affinity for the recombinant $\mathrm{D}_{3}$ receptor and $\mathrm{D}_{2}$ receptor in rat striatal membranes, ${ }^{15}$ and similar affinities in rat striatal $\left(\mathrm{D}_{2}\right)$ and cerebellar $\left(\mathrm{D}_{3}\right)$ membranes. ${ }^{18}$ The affinity of cariprazine for the human $D_{3}$ receptor was not affected by the Ser9Gly polymorphism, ${ }^{17}$ which has been associated with tolerability and response to antipsychotics. ${ }^{19}$

Cariprazine has high affinity $(\mathrm{pKi}>9.0)$ for the human $5-\mathrm{HT}_{2 \mathrm{~B}}$ receptor in CHO-K1 cells, in the range of the affinity for $\mathrm{D}_{2}$ receptors. ${ }^{15}$ Its affinity for human and rat $5-\mathrm{HT}_{1 \mathrm{~A}}$ receptors is also high, but lower than the affinity for $\mathrm{D}_{2}$ receptors. ${ }^{15}$ However, a separate study reported similar affinity for cloned human 5- $\mathrm{HT}_{1 \mathrm{~A}}$ and $\mathrm{D}_{2}$ receptors. ${ }^{20}$ Cariprazine binds with moderate affinity $(7.0<\mathrm{pKi}<8.0)$ to human $\sigma_{1}, 5-\mathrm{HT}_{2 \mathrm{~A}}$, and human histamine $\mathrm{H}_{1}$ receptors, and shows less affinity $(\mathrm{pKi}<7.0)$ for human $5-\mathrm{HT}_{2 \mathrm{C}}, 5-\mathrm{HT}_{7}, \alpha_{1 \mathrm{~A}}$, and $\alpha_{1 \mathrm{D}} \cdot{ }^{15}$ However, in another study, cariprazine showed higher affinity for the human histamine $\mathrm{H}_{1}$ receptor. ${ }^{20}$ Low-affinity binding ( $\mathrm{pKi}<6.0$ ) characterizes the interaction of cariprazine with $5-\mathrm{HT}_{6}, \alpha_{1 \mathrm{~B}}-\alpha_{2 \mathrm{~A}}$ - and $\beta$-adrenoceptors and DA and 5-HT transporters.

According to Kiss et al ${ }^{15}$ cariprazine has low in vitro affinity (less than $20 \%$ displacement at $1 \mathrm{mM}$ ) for a variety 
of neurotransmitter receptors, ion channels, and transporters, including adenosine $\mathrm{A}_{1}, \mathrm{~A}_{2 \mathrm{~A}}$, and $\mathrm{A}_{3} ; \mathrm{a}_{2 \mathrm{~A}}$ and $\mathrm{a}_{2 \mathrm{C}}$ adrenoceptors; cannabinoid $\mathrm{CB}_{1}$ and $\mathrm{CB}_{2}$; cholecystokinin $\mathrm{CCK}_{1}$ and $\mathrm{CCK}_{2}$; corticotropin $\mathrm{CRF} 1$; dopamine $\mathrm{D}_{1}, \mathrm{D}_{4.2}$, and $\mathrm{D}_{5}$; estrogen ER- $\alpha$ and ER- $\beta$; $\mathrm{GABA}_{\mathrm{A}}$ and $\mathrm{GABA}_{\mathrm{B}}$; galanin $\mathrm{GAL}_{1}$ and $\mathrm{GAL}_{2}$; glucocorticoid; glutamate AMPA ( $\alpha$-amino-3-hydroxy-5methyl-4-isoxazolepropionic acid), kainate and $N$-methyl-Daspartic acid (NMDA) subtypes; histamine $\mathrm{H}_{2}, \mathrm{H}_{3}$, and $\mathrm{H}_{4}$; muscarinic $\mathrm{M}_{1-5}$; nicotinic; orphanin $\mathrm{ORL}_{1}$; opiates $\delta$, $\kappa$, and $\mu$; potassium channel human Ether-a-go-go-related gene; progesterone; $5-\mathrm{HT}_{3}, 5-\mathrm{HT}_{4}, 5-\mathrm{HT}_{5 \mathrm{~A}}$, and 5- $\mathrm{HT}_{6}$ subtypes; $\sigma_{2} ; \mathrm{Ca}^{2+} \mathrm{L}$-type and $\mathrm{N}$-type channels; $\mathrm{Na}^{+} 1$ and 2 channels; norepinephrine, adenosine, and choline transporters. Cariprazine $(10 \mathrm{mM})$ does not inhibit $\mathrm{Ca}^{2+}$-adenosintriphosphatase, $\mathrm{Na}^{+} / \mathrm{K}^{+}$-adenosine triphosphatase, acetylcholinesterase, 3-hydroxy-3-methylglutaryl-coenzyme A reductase, or acylcoenzyme A-cholesterol acyltransferase.

\section{Functional effects of cariprazine on its main targets}

Cariprazine's ability to stimulate or inhibit the activity of $\mathrm{D}_{2}$ and $\mathrm{D}_{3}$ receptors has been investigated in vitro using various assays, including G-protein-dependent and independent signaling. In the $\left[{ }^{35} \mathrm{~S}\right]$ guanosine $5^{\prime}$-O-[gamma-thio] triphosphate (GTP $\gamma \mathrm{S})$-binding assay, cariprazine behaved as a silent antagonist of native rat and recombinant human $\mathrm{D}_{2}$ and $\mathrm{D}_{3}$ receptors, blocking $\mathrm{DA}$-induced stimulation of $\left[{ }^{35} \mathrm{~S}\right]$ GTP $\gamma \mathrm{S}$ binding in rat striatal membranes and $\mathrm{CHO}-\mathrm{hD}_{3}$ cells, displaying the highest antagonist potency $(\mathrm{pKb}=8.95$ and 9.50, respectively) among various antipsychotics, including aripiprazole, haloperidol, olanzapine, and risperidone. ${ }^{15}$ Cariprazine had high potency $(\mathrm{pKb}=9.12)$ in blocking DAstimulated $\left[{ }^{35} \mathrm{~S}\right] \mathrm{GTPyS}$ binding in HEK- $\mathrm{D}_{2}$ cells expressing human receptor, surpassed only by aripiprazole $(\mathrm{pKb}=9.33)$. Cariprazine had no agonist effect at $\mathrm{D}_{2}$ and $\mathrm{D}_{3}$ receptors in this assay. ${ }^{15}$ In mouse A9 cells cotransfected with human $\mathrm{D}_{2}$ receptor and Gqo5 protein, cariprazine is a partial agonist. It potently stimulated inositol phosphate (IP) formation (negative log of median effective concentration $\left[\mathrm{pEC}_{50}\right]$ 8.50; $\mathrm{E}_{\max }[$ maximum effect $] \sim 30 \%$ ), but prevented IP formation induced by the selective $\mathrm{D}_{2}$-receptor agonist quinpirole. ${ }^{15}$ In human $\mathrm{D}_{2 \mathrm{~L}}$-expressing cells, cariprazine showed partial agonist activity in IP ( $\left.\mathrm{E}_{\max } \sim 20 \%\right)$ and inhibition of forskolin-stimulated cyclic adenosine monophosphate (cAMP)production assays $\left(\mathrm{E}_{\max } \sim 60 \%\right){ }^{21}$ However, the maximal effect of cariprazine and other partial agonists at $D_{2}$ receptors depends on the receptor-expression level. ${ }^{17}$

Cariprazine is $\mathrm{a}_{3}$-receptor partial agonist, potently inhibiting forskolin-stimulated cAMP production in $\mathrm{CHO}-\mathrm{hD}_{3}$ cells $\left(\mathrm{pEC}_{50}\right.$ 8.58) with high intrinsic activity $\left(\mathrm{E}_{\max } 71 \%\right)$. It partially prevented the inhibition of forskolin-induced accumulation of cAMP by the $\mathrm{D}_{2} / \mathrm{D}_{3}$ agonist 7-OH-DPAT (dipropylamino-7-hydroxy-1,2,3,4 tetrahydronaphtalene) $\left(\mathrm{E}_{\max } 27 \%\right) .{ }^{15}$ In the $\mathrm{D}_{2}$-receptor/ $\beta$-arrestin assay, a G-proteinindependent signaling pathway, it showed weak agonist activity $\left(\mathrm{E}_{\max } 10 \%\right)$ but potent antagonist effect. ${ }^{21}$

Contraction of isolated rat stomach fundus strips is a typical response elicited by $5-\mathrm{HT}_{2 \mathrm{~B}}$-receptor agonists. Cariprazine had no effect by itself, but potently inhibited 5-HT-induced contraction (half-maximal inhibitory concentration $\left[\mathrm{IC}_{50}\right]$ $12.9 \mathrm{nM}$ ), indicating that it is a pure antagonist of the rat $5-\mathrm{HT}_{2 \mathrm{~B}}$ receptors. ${ }^{15}$ To the best of our knowledge, no data are available on the functional effects of cariprazine on human $5-\mathrm{HT}_{2 \mathrm{~B}}$ receptors.

Partial agonism characterizes the activity of cariprazine at $5-\mathrm{HT}_{1 \mathrm{~A}}$ receptors. In membranes prepared from rat hippocampus, the compound potently stimulated $\left[{ }^{35} \mathrm{~S}\right] \mathrm{GTP} \gamma \mathrm{S}$ binding but had moderate intrinsic activity $\left(\mathrm{E}_{\max } 38.6 \%\right)$ compared to the full agonist 8-OH-DPAT. ${ }^{15}$

Cariprazine did not stimulate IP formation in $\mathrm{CHO}$ cells expressing human $5-\mathrm{HT}_{2 \mathrm{~A}}$ receptors, but inhibited the effect of the 5-HT $2 \mathrm{~A}$-receptor agonist DOI (2,5-dimethoxy-4iodoamphetamine $).{ }^{15}$ The high $\mathrm{IC}_{50}(403 \mathrm{nM})$ indicates moderate antagonism at $5-\mathrm{HT}_{2 \mathrm{~A}}$ receptors. In isolated guinea pig trachea preparation, histamine caused contraction through activation of the $\mathrm{H}_{1}$ receptor. Cariprazine had no effect by itself, but antagonized the histamine-induced contraction $\left(\mathrm{IC}_{50} 149 \mathrm{nM}\right)$, indicating $\mathrm{H}_{1}$ receptor-antagonist activity. ${ }^{15}$

\section{In vivo studies}

These have mainly focused on dopaminergic and serotonergic neuronal activity and behavioral characterization in tests predictive of antipsychotic activity and side effects. Cariprazine enhanced the turnover/metabolism of DA preferentially in the mouse olfactory tubercle, compared to the striatum and frontal cortex. ${ }^{15}$ Like atypical antipsychotic drugs, ${ }^{22,23}$ longterm treatment with cariprazine preferentially suppressed the spontaneous activity of mesolimbic DA neurons (suppression ranged between $45 \%$ and $66 \%$ at $0.1-1.0 \mathrm{mg} / \mathrm{kg}$ orally, once daily for 21 days), but had no effect on mesostriatal DA neurons. ${ }^{24}$ Long-term cariprazine $(0.06-0.6 \mathrm{mg} / \mathrm{kg}$ intraperitoneally for 28 days) induced adaptive changes in dopaminergic, serotonergic, and glutamatergic receptors in various rat brain regions. An increase in $\mathrm{D}_{2}$ receptors was observed in the medial prefrontal cortex, nucleus accumbens, medial and lateral striata, and hippocampus (only at the highest dose). $\mathrm{D}_{4}$-receptor density increased in the nucleus accumbens and 
the medial and lateral striata. $\mathrm{D}_{3}$-receptor density increased in the olfactory tubercle and islands of Calleja, but no effect was seen on the $\mathrm{D}_{1}$ receptor. ${ }^{25}$ Cariprazine increased $5-\mathrm{HT}_{1 \mathrm{~A}}$-receptor density in the rat hippocampus CA1 and CA3 subregions and in the medial and dorsal prefrontal cortex, but no changes in $5-\mathrm{HT}_{2 \mathrm{~A}}$-receptor density were observed in any brain regions. ${ }^{25}$ Glutamate receptors NMDA and AMPA are regulated in opposite directions by long-term cariprazine, which reduced NMDA-receptor levels in the nucleus accumbens and caudate and hippocampal subregions and increased AMPA-receptor density in the hippocampus CA1 and CA3 areas. ${ }^{26}$

The in vivo effects of cariprazine on DA synthesis depend on the level of biosynthetic activity. In mice given $\gamma$-butyrolactone, which reduces impulse flow in DA neurons and stimulates DA synthesis and DOPA (3,4-dihydroxyphenylalanine) accumulation in the striatum, cariprazine behaves as a $\mathrm{D}_{2}$-autoreceptor agonist partially suppressing DOPA accumulation at 3 and $10 \mathrm{mg} / \mathrm{kg}$, but also as an antagonist (at 1 and $3 \mathrm{mg} / \mathrm{kg}$ ), fully blocking the suppression of DA synthesis induced by the $\mathrm{D}_{2}$-receptor agonist apomorphine. ${ }^{15}$ Likewise, the reserpine-induced increase in DA synthesis in the mouse striatum was completely reversed by $0.3 \mathrm{mg} / \mathrm{kg}$ cariprazine, which, differently from apomorphine, did not reduce synthesis below control levels. ${ }^{15}$ This suggests that cariprazine behaves as a partial agonist in this model.

Cariprazine is effective in behavioral tests sensitive to antipsychotic drugs, including inhibition of apomorphineinduced climbing in mice (effective dose for $50 \%\left[\mathrm{ED}_{50}\right]$ $0.27 \mathrm{mg} / \mathrm{kg}$ ), inhibition of amphetamine-, phencyclidine-, and MK-801-induced motor activity in rats $\left(\mathrm{ED}_{50} 0.12 \mathrm{mg} / \mathrm{kg}\right.$, $0.09 \mathrm{mg} / \mathrm{kg}$ against amphetamine and phencyclidine, respectively, while $0.025-0.4 \mathrm{mg} / \mathrm{kg}$ was the dose range for antagonism of MK-801-induced locomotion). Cariprazine inhibited the conditioned avoidance response $\left(\mathrm{ED}_{50} 0.84 \mathrm{mg} / \mathrm{kg}\right)^{27}$ and apomorphine-induced deficits of prepulse inhibition of the startle reflex $(0.3-1.0 \mathrm{mg} / \mathrm{kg}),{ }^{28}$ but unlike classical neuroleptic drugs, it did not cause catalepsy (maximum dose evaluated $85.0 \mathrm{mg} / \mathrm{kg}$ ). In the water-maze paradigm of spatial learning and memory, cariprazine $(0.02-2.0 \mathrm{mg} / \mathrm{kg})$ counteracted the deficit induced by scopolamine. ${ }^{27}$ Cariprazine $(0.005-0.01 \mathrm{mg} /$ $\mathrm{kg}$ ) improved the phencyclidine-induced deficit of working and recognition memory in mice. ${ }^{29}$ Cariprazine $(0.05-0.25 \mathrm{mg} /$ $\mathrm{kg}$ ) reversed subchronic phencyclidine-induced deficits in the novel object-recognition test, reversal-learning paradigm, and social avoidance in rats and phencyclidine-induced increase in extracellular glutamate in the rat prefrontal cortex. ${ }^{30}$ It shares this latter effect with aripiprazole ${ }^{30,31}$ and atypical antipsychotic drugs. $^{32}$ Cariprazine $(0.2 \mathrm{mg} / \mathrm{kg}$ twice daily for 21 days $)$ showed antidepressant-like effects in the mouse model of chronic stress-induced anhedonia, ${ }^{33}$ in the rat model of stressinduced anhedonia (at $0.03-0.25 \mathrm{mg} / \mathrm{kg} /$ day for 5 weeks), ${ }^{34}$ and anxiolytic-like effects in the punished-drinking and ultrasonic vocalization tests. ${ }^{27}$ The antianhedonic effects of cariprazine appear to be $\mathrm{D}_{3}$-dependent, as the drug had no effect in $\mathrm{D}_{3}$-knockout mice. ${ }^{29,33}$ Finally, cariprazine showed antimaniclike activity in ouabain (rat)- and amphetamine/chlordiazepoxide (mice)-induced hyperactivity mania models. ${ }^{35}$

A positron emission tomography study in monkeys found that cariprazine up to $300 \mu \mathrm{g} / \mathrm{kg}$ induced approximately $94 \%$ $\mathrm{D}_{2} / \mathrm{D}_{3}$-receptor occupancy, while occupancy of the $5-\mathrm{HT}_{1 \mathrm{~A}}$ receptor in the raphe nuclei was approximately $30 \%$, thus confirming in vitro data on the compound's affinity. Cariprazine displaced the agonist and antagonist tracers to the same degree, suggesting it acts as an antagonist at the $\mathrm{D}_{2} / \mathrm{D}_{3}$ receptors. ${ }^{36}$ Cariprazine $1 \mathrm{mg} / \mathrm{kg}$ fully inhibited the uptake of $\left[{ }^{3} \mathrm{H}\right]$ (+)-PHNO (4 propyl-9-hydroxynaphthoxazine), $\mathrm{a} \mathrm{D}_{3}$-receptor ligand, in rat cerebellum. ${ }^{18}$ In healthy subjects, it occupied $63 \%-79 \%$ of striatal $\mathrm{D}_{2} / \mathrm{D}_{3}$ receptors 4 hours after $0.5-1 \mathrm{mg}$ doses repeated for 2-12 days. After repeated oral dosing in schizophrenic patients, $\mathrm{D}_{2} / \mathrm{D}_{3}$-receptor occupancy ranged from $69 \%$ to $75 \%$ at $1.5 \mathrm{mg}$ to $>90 \%$ at $3 \mathrm{mg}$, regardless of the region examined; similar results were observed for its desmethyl and didesmethyl derivatives, the main metabolites in man, and animals. ${ }^{13}$

\section{Pharmacokinetics}

The pharmacokinetic data are summarized from three ample reviews of cariprazine, ${ }^{12,13,37}$ with supplemental data from abstracts $^{38,39}$ but only one full research report. ${ }^{40}$

Cariprazine is rapidly absorbed, reaching peak concentrations between 3 and 4 hours after oral dosing in healthy subjects. Its pharmacokinetics were linear in terms of area under the concentration-time curve (AUC) but maximum concentrations were more than proportional within the dose range from 3 to $5 \mathrm{mg}$ in healthy subjects. Food marginally delayed the absorption of cariprazine, but did not affect the extent of its absorption after a single $2 \mathrm{mg}$ oral dose. ${ }^{12,13}$

With continued administration, cariprazine markedly accumulated in plasma but concentrations remained doseproportional within the dose-range of $0.5-12.5 \mathrm{mg} /$ day in schizophrenic patients. Mean half-life $\left(t_{1 / 2}\right)$ was 2-5 days (1.5-12.5 mg/day). ${ }^{12,13}$

Once absorbed, cariprazine behaves like most lipophilic antipsychotics, extensively distributing in tissues, with 
large apparent volume of distributions in animal studies $\left(6.5-7.8 \mathrm{~L} / \mathrm{kg}\right.$ in rats and $16-19 \mathrm{~L} / \mathrm{kg}$ in dogs). ${ }^{13}$ In the rat, it reached brain concentrations about eight times those in plasma. In nonhuman primates, over $6 \%$ of an intravenous dose was found in the brain at 2 minutes, with $3 \%-4 \%$ remaining in this tissue after 90 minutes, further indicating slow washout. ${ }^{41}$

Cariprazine is then primarily cleared by hepatic metabolism, as are most lipophilic antipsychotics. In hepatic microsomes in vitro, it primarily undergoes dealkylation, hydroxylation, $\mathrm{N}$-oxidation, and cleavage by cytochrome P450 (CYP)3A4 and to a lesser extent by CYP2D6. ${ }^{38}$ Except for dealkylation of the $N, N$-dimethylcarbamoylcyclohexyl-amine group to the desmethyl and didesmethyl derivatives, there is no information on the pharmacological activity and contribution to the overall outcomes of other metabolites. ${ }^{39,40}$ Brain uptake and concentrations of these metabolites compared to the parent compound have not yet been reported. However, in patients with schizophrenia, exposure to desmethyl-cariprazine was dose-proportionally $30 \%-40 \%$ of the parent compound on the last day of dosing with $12.5 \mathrm{mg}$ cariprazine; exposure to didesmethyl-cariprazine exceeded that of cariprazine three- to sixfold (Table 1). Steady state for desmethyl-cariprazine was achieved within 3 weeks of dosing, as for cariprazine, while didesmethyl-cariprazine did not reach equilibrium because of its extremely slow elimination ( $t_{1 / 2} 2-3$ weeks $)$.

There are still no pharmacokinetic or metabolic data for specific patient populations such as the elderly, CYP2D6 phenotype subjects, and patients with diseases of drugeliminating organs. Information is also lacking about potential interactions involving cariprazine. However, in human hepatocytes, cariprazine was a weak competitive inhibitor of CYP2D6 and CYP3A4 and did not induce CYP3A4.

It is not known whether cariprazine or its main metabolites act as substrates or inhibitors of P-glycoprotein with the potential of influencing the pharmacokinetics and hence the pharmacodynamics of coadministered drugs through inhibition of P-glycoprotein-mediated efflux transport, as do many other antipsychotics. ${ }^{42}$

\section{Efficacy of cariprazine}

Information on cariprazine's efficacy in schizophrenia and bipolar disorders, including bipolar mania/mixed episodes and bipolar depression, comes mainly from press releases from the manufacturer, ${ }^{43,44}$ or abstracts presented at scientific meetings, but no clinical studies have been published in peer-reviewed journals, some studies have not been submitted to the FDA. Findings have been reviewed in more detail elsewhere. ${ }^{43-48}$
Table I Some pharmacokinetic parameters of cariprazine and its active metabolites

\begin{tabular}{llll}
\hline Compound & $\begin{array}{l}\text { Elimination } \\
\text { half-life } \\
\text { (days) }\end{array}$ & $\begin{array}{l}\text { Time to reach } \\
\text { steady state } \\
\text { (days) }\end{array}$ & $\begin{array}{l}\text { Metabolite- } \\
\text { to-parent } \\
\text { drug ratio }\end{array}$ \\
\hline Cariprazine & $2-6$ & $\leq 7$ & $0.3-0.4^{\mathrm{a}}$ \\
$\begin{array}{l}\text { Desmethyl- } \\
\text { cariprazine }\end{array}$ & $\mathrm{NR}$ & $\leq 7$ & $3-6^{\mathrm{a}}$ \\
$\begin{array}{l}\text { Didesmethyl- } \\
\text { cariprazine }\end{array}$ & $|4-2|$ & $\geq 21$ & \\
\hline
\end{tabular}

Note: after 3 weeks of dosing in healthy volunteers and schizophrenic patients. Abbreviation: NR, not reported.

The compound's short-term efficacy and safety profile in schizophrenic patients has been investigated in five doubleblind, randomized efficacy trials (two Phase II and three Phase III trials) of six weeks' duration, comprising 3,087 patients with schizophrenia, age range 18-65 years. Efficacy and safety in patients with bipolar disorder were investigated in five double-blind, randomized efficacy trials (three Phase II and two Phase III) of 3-8 weeks' duration, comprising 1,880 patients with the same age range. .3,44 $^{4}$

Only a few studies have been submitted to the FDA for the approval of cariprazine. A new-drug application (the vehicle in the US through which drug sponsors formally propose that the FDA approve a new pharmaceutical for sale and marketing) has been submitted for the treatment of schizophrenia and for the acute treatment of manic or mixed episodes associated with bipolar I disorder. The data on schizophrenia come from three trials in 1,795 patients: two fixed-dose studies with active controls (a Phase II trial with risperidone $4.0 \mathrm{mg} /$ day and a Phase III study with aripiprazole $10 \mathrm{mg} /$ day), and one Phase III fixed-flexible placebo-controlled dose trial. ${ }^{43,49}$ The application for the acute treatment of manic or mixed episodes associated with bipolar I disorder includes results from three placebo-controlled trials in 1,047 patients, two flexible-dose trials (one Phase II and one Phase III), and one Phase III fixed-flexible dose trial. ${ }^{44,49}$

\section{Schizophrenia}

Superiority over placebo on the Positive and Negative Syndrome Scale (PANSS) total score was evidenced at different dosages: $1.5,3.0,4.5,6.0$, and $9.0 \mathrm{mg}$ /day. In clinical trials with an active control, cariprazine and risperidone were significantly superior to placebo on PANSS total score and both positive (PANSS positive subscale) and negative (PANSS negative subscale and Negative Symptom Assessment 16) symptoms of schizophrenia. Significant improvement at week 6 for cariprazine and risperidone versus placebo was 
also seen on the Clinical Global Impressions - Severity and Clinical Global Impressions - Improvement scales. Doseresponse improvements on each of the efficacy outcomes were observed for cariprazine, but the efficacy outcomes were numerically highest for risperidone. No differences in the PANSS total score were reported with aripiprazole, although statistically significant improvements were seen with cariprazine and aripiprazole compared to placebo.

In a Phase II trial (not submitted to the FDA) with 392 participants, $46 \%$ discontinued the trial prematurely, with a similar proportion of discontinuation between the low-dose and high-dose groups, primarily for worsening of schizophrenia. No significant difference from placebo was observed for the primary efficacy parameter. No information is available for long-term efficacy. ${ }^{43} \mathrm{~A}$ randomized long-term controlled trial for the prevention of relapses of schizophrenia is ongoing, but no data are available yet.

\section{Bipolar disorder}

Three Phase III short-term randomized controlled trials of cariprazine in patients with bipolar mania/mixed episodes and two Phase II trials in bipolar depression (one in bipolar depression is still in progress) have evaluated efficacy in bipolar disorder. No Phase II or Phase III trials have compared cariprazine with an active control.

The primary efficacy measure in trials for bipolar mania/ mixed episodes was the Young Mania Rating Scale (YMRS) total score, and the primary outcome was change from baseline at the 3-week end point. Superiority over placebo on the primary outcome was observed at dosages of 3-12 mg/day. Cariprazine-treated subjects had significantly better rates of YMRS response (at least 50\% reduction from baseline) and remission. The primary efficacy measure in trials for bipolar depression was the Montgomery-Åsberg Depression Rating Scale (MADRS), and the primary end point was change from baseline to week 8 in the MADRS total score compared to placebo. The overall difference between cariprazine- and placebo-treated subjects was not significant. ${ }^{44-47}$

\section{Cariprazine safety and tolerability}

Short-term safety and tolerability

Again, information is only available from posters and manufacturers' press releases; no clinical trials have been published at the date of this review. Citrome mentions in his reviews that the drug's short-term safety profile has been evaluated in two randomized double-blind Phase II trials and two randomized double-blind Phase III trials of 6 weeks' duration, for a total of 2,187 patients with schizophrenia, and in three randomized double-blind Phase II trials and two Phase III trials of 3-8 weeks' duration, with 2,139 patients with bipolar disorder. ${ }^{43-47}$

Early data in schizophrenic patients suggest that cariprazine is well tolerated, with a discontinuation rate similar to placebo. ${ }^{43}$ The most common adverse events reported with cariprazine were insomnia, extrapyramidal disorder, sedation, akathisia, nausea, dizziness, vomiting, anxiety, and constipation. No clinically meaningful changes were observed for cariprazine in metabolic variables, prolactin or corrected QT (QTc) prolongation ( $>500 \mathrm{~ms}$ ). Potentially clinically significant weight gain ( $\geq 7 \%$ increase from baseline) was greater with risperidone $(16.7 \%)$ than cariprazine (respectively, $8.5 \%, 10.7 \%$, and $4.9 \%$ for $1.5,3.0$, and $4.5 \mathrm{mg} /$ day) or placebo $(2 \%) .{ }^{43}$ Premature discontinuation rates were similar to placebo, but higher than aripiprazole: $33 \%$ for cariprazine $3 \mathrm{mg} /$ day, $38 \%$ for cariprazine $6 \mathrm{mg} /$ day, $25 \%$ for $10 \mathrm{mg}$ /day aripiprazole, and $38 \%$ for placebo. Discontinuation rates similar to placebo were confirmed in the second Phase III trial: $36 \%$ for cariprazine $3-6 \mathrm{mg} /$ day, $42 \%$ for cariprazine 6-9 mg/day, and 40\% for placebo.

In patients with bipolar disorder, the most common adverse events reported with cariprazine (incidence of at least $5 \%$ ) were again extrapyramidal disorder, akathisia, insomnia, vomiting, restlessness, sedation, blurred vision, tremor, dyspepsia, dizziness, diarrhea, somnolence, pyrexia, and pain in extremities. Early data from a Phase III trial suggest that the discontinuation rate due to adverse events is higher than placebo: respectively, $9 \%, 15 \%$, and $5 \%$ of patients with cariprazine 3-6 mg/day, 6-12 mg/day, and placebo. ${ }^{44}$ In another Phase III trial, 15 out of 312 cariprazine-treated patients discontinued because of an adverse event, with five because of akathisia. ${ }^{45}$ Discontinuation due to adverse events also occurred with $9 \%$ of patients compared to $3 \%$ in the placebo arm in a Phase II trial. Mean changes in blood pressure and pulse were greater in the cariprazine group than with placebo. The incidence of orthostatic hypotension or electrocardiogram (ECG) changes was similar for cariprazine- and placebo-treated subjects. Mean changes in body weight from baseline to end of treatment were small and similar in both treatment groups (placebo $0.30 \mathrm{~kg}$, cariprazine $0.43 \mathrm{~kg}$ ). None of those receiving cariprazine had an ECG QT interval in excess of $500 \mathrm{~ms}^{44}$

\section{Long-term safety and tolerability}

Additional information about safety and tolerability are available from an ongoing 48-week Phase III open-label 
trial in about 900 patients with schizophrenia. According to a manufacturer's press release, the most common adverse events (incidence of at least 10\%) were akathisia, insomnia, restlessness, extrapyramidal disorder, weight gain, and headache..$^{50}$ There was no sign of treatment-emergent hepatic abnormalities. Mean prolactin levels dropped from baseline. No clinically significant trends or changes were noted in most metabolic variables, but insulin tended to rise from baseline. Potentially clinically significant weight gain was observed in $33 \%$ of patients; weight loss of at least $7 \%$ from baseline was observed in $8 \%$. Although mean changes in blood pressure and pulse rate were small, orthostatic hypotension when changing from the supine to standing position was noted in $25 \%$. There were no signs of abnormalities in the ECG QT interval. ${ }^{43}$

No long-term safety and tolerability data are available for patients with acute mania or bipolar depression: a 16-week, open-label trial in patients with bipolar disorder has been completed but not publicly presented. ${ }^{44}$

\section{Conclusion}

The development of novel antipsychotic drugs in the last few decades has been based on the widely accepted hypothesis that inhibition of $\mathrm{D}_{2}$ receptor-mediated function in different brain circuits is responsible for antipsychotic (limbic and cortical circuits) and motor side effects (nigrostriatal circuit). In the attempt to reduce motor side effects and improve clinical efficacy of antipsychotic drugs, particularly in the domains of cognitive deficits and negative symptoms, new molecules which combined $\mathrm{D}_{2}$-receptor antagonism with potent $5-\mathrm{HT}_{2 \mathrm{~A}}$-receptor blockade or $5-\mathrm{HT}_{1 \mathrm{~A}}$-receptor agonism were developed. More recently, molecules displaying $\mathrm{D}_{2} / \mathrm{D}_{3}$ and $5-\mathrm{HT}_{1 \mathrm{~A}}$-receptor partial agonism, such as aripiprazole, were added to the therapeutic armamentarium. Pharmacologically, cariprazine shows close similarities with aripiprazole, except for its preferential affinity for human $\mathrm{D}_{3}$ receptors and less affinity for $\mathrm{H}_{1}, 5-\mathrm{HT}_{2 \mathrm{~A}}$, and $5-\mathrm{HT}_{2 \mathrm{C}}$ receptors. This pharmacological profile is expected to confer to cariprazine a preferential activity on mesolimbic DA mechanisms, where $\mathrm{D}_{3}$ receptors are preferentially expressed. This is consistent with a preferential effect of cariprazine on DA synthesis in limbic regions of the rat brain. In line with the role of $\mathrm{D}_{3}$ receptors in cognition and emotional behavior evidenced in animal studies, ${ }^{16} \mathrm{D}_{3}$ receptors play a major role in the cognitive and antidepressant-like effects of cariprazine in mice.

Agonism/partial agonism at $5-\mathrm{HT}_{1 \mathrm{~A}}$ receptors, a characteristic shared by cariprazine, aripiprazole, and other antipsychotics, may contribute to the lack of cataleptogenic activity of cariprazine and its ability to improve cognitive deficits in animal models. ${ }^{20}$ Moderate affinity for $\mathrm{H}_{1}$ and $5-\mathrm{HT}_{2 \mathrm{C}}$ receptors suggests low propensity of cariprazine to cause sedation and body-weight gain, side effects that are commonly associated with blockade of these receptors. ${ }^{51}$ Although cariprazine is a potent $5-\mathrm{HT}_{2 \mathrm{~B}}$-receptor antagonist in the rat stomach fundus, ${ }^{15}$ to the best of our knowledge no data are available on the functional effects of cariprazine on human $5-\mathrm{HT}_{2 \mathrm{~B}}$ receptors. Given the very high affinity of cariprazine for human $5-\mathrm{HT}_{2 \mathrm{~B}}$ receptors whose stimulation has been involved in serious side effects, ${ }^{52}$ further studies are needed to exclude any stimulating effects of cariprazine or its metabolites on human receptors. With the exception of the role of $\mathrm{D}_{3}$ receptors in the antidepressant-like and cognitive effects of cariprazine, whether the preferential effect or combined actions of cariprazine on $\mathrm{D}_{2} / \mathrm{D}_{3}, 5-\mathrm{HT}_{2 \mathrm{~B}}, 5-\mathrm{HT}_{2 \mathrm{~A}}$, $5-\mathrm{HT}_{1 \mathrm{~A}}$, and $\mathrm{H}_{1}$ receptors contribute to its efficacy/side-effect profile in animal studies remains to be investigated.

Like aripiprazole and many other antipsychotics, cariprazine is metabolized in the liver by CYP3A4, with its wide individual variability of expression levels and susceptibility to drug interactions, but the polymorphic CYP2D6 plays a minor role in cariprazine metabolism, suggesting it has less influence on the dispositions of this new compound and its active metabolites compared to aripiprazole and other 2D6 substrates with antipsychotic efficacy (eg, risperidone). Cariprazine, particularly its main metabolite didesmethylcariprazine, has an unusually long terminal half-life, meaning that the total active drug (parent compound + metabolites) will attain a steady state after weeks of dosing, although this theoretically may result in low fluctuations in plasma and target-receptor concentrations of the drug at a steady state. In fact, cariprazine is being considered for an "oral depot" with weekly or less administration, which is quite novel and different from currently available antipsychotic agents (longacting injectable antipsychotics aside). We await the results of current studies to learn more about the potential advantages (and disadvantages) of the once-weekly oral formulation of cariprazine in clinical practice and patient compliance compared to daily oral antipsychotic agents.

Major concerns on the evaluation of the clinical role of cariprazine come from the lack of original studies published in peer-reviewed journals and because some studies have not submitted for FDA evaluation. In fact, most data come from posters and manufacturers' press releases. Thus, according to available data, cariprazine appears superior to placebo in patients with schizophrenia and bipolar mania/ mixed episodes (but not in bipolar depression). Very little 
information is available so far about comparative efficacy and safety between cariprazine and other second-generation antipsychotic or antimanic agents. Although cariprazine was effective and generally well tolerated in several short-term placebo-controlled trials, these enrolled only small numbers of highly selected patients, and studies that compared cariprazine with an active comparator were not designed to test the differences among antipsychotics directly. These weaknesses limit the general extension of the results to patients with other psychological or clinical comorbidities, with comorbid drug use and/or dependence. Information is also lacking on the efficacy and safety of cariprazine in special populations, such as children, adolescents, elderly patients, and subjects with treatment-refractory schizophrenia.

Other preliminary studies show minimal risks for metabolic abnormalities, like some other new antipsychotics, ${ }^{7-11}$ and there is little weight gain and no significant increase in QTc. This might possibly give cariprazine an advantage over some atypical antipsychotics, but published clinical trials are expected to assess the safety profile of this potential antipsychotic. In addition, further trials with a broader population of patients would be useful to explore these areas. The only data on the drug's long-term efficacy and safety come from a single open-label study, ${ }^{50}$ and although none of the patients treated with cariprazine experienced significant QTc change, the risk of Torsades de pointes in the general populations remain unknown. Additional studies on larger samples of patients are therefore required.

Cariprazine also appears to have a low potential for weight gain and adverse metabolic effects, but again longerterm trials are needed to assess the risk of new-onset diabetes, which is of particular concern with second-generation antipsychotics. ${ }^{53,54}$ Long-term treatment with antipsychotic drugs, especially at high dosages, is also associated with the risk of tardive dyskinesia, and this potential adverse reaction may be underestimated because of the limited information so far from long-term clinical trials.

Lastly, the clinical advantages of the new antipsychotic agents have not been evaluated in direct superioritycomparative studies. The lack of well-designed long-term comparative studies and the unnecessary and excessive use of placebo in the few short-term available studies add to the difficulty of assessing its benefit-risk profile. Well-designed, appropriately powered clinical studies are therefore needed to elaborate the therapeutic role of this potential antipsychotic in schizophrenia and bipolar mania and as an adjunctive treatment option for major depressive disorder.

\section{Disclosure}

The authors report no conflicts of interest in this work.

\section{References}

1. Correll CU, Leucht S, Kane JM. Lower risk for tardive dyskinesia associated with second-generation antipsychotics: a systematic review of 1-year studies. Am J Psychiatry. 2004;161(3):414-425.

2. Luft B, Taylor D. A review of atypical antipsychotic drugs versus conventional medication in schizophrenia. Expert Opin Pharmacother. 2006;7(13):1739-1748.

3. Tandon R, Jibson MD. Efficacy of newer generation antipsychotics in the treatment of schizophrenia. Psychoneuroendocrinology. 2003; 28 Suppl 1:9-26.

4. Dorado P, Berecz R, Peñas-Lledó EM, Llerena A. Antipsychotic drugs and QTc prolongation: the potential role of CYP2D6 genetic polymorphism. Expert Opin Drug Metab Toxicol. 2007;3(1):9-19.

5. Haddad P. Weight change with atypical antipsychotics in the treatment of schizophrenia. J Psychopharmacol. 2005;19(Suppl 6):16-27.

6. Haddad PM, Sharma SG. Adverse effects of atypical antipsychotics: differential risk and clinical implications. CNS Drugs. 2007;21(11): 911-936.

7. Caccia S, Pasina L, Nobili A. New atypical antipsychotics for schizophrenia: iloperidone. Drug Des Devel Ther. 2010;4:33-48.

8. Caccia S, Pasina L, Nobili A. Critical appraisal of lurasidone in the management of schizophrenia. Neuropsychiatr Dis Treat. 2012;8: $155-168$.

9. Chue P, Chue J. A review of paliperidone palmitate. Expert Rev Neurother. 2012;12(12):1383-1397.

10. Citrome L. Asenapine for schizophrenia and bipolar disorder: a review of the efficacy and safety profile for this newly approved sublingually absorbed second-generation antipsychotic. Int J Clin Pract. 2009;63(12):1762-1784.

11. Kishi T, Matsuda Y, Nakamura H, Iwata N. Blonanserin for schizophrenia: systematic review and meta-analysis of double-blind, randomized, controlled trials. J Psychiatr Res. 2013;47(2):149-154.

12. Citrome L. Cariprazine: chemistry, pharmacodynamics, pharmacokinetics, and metabolism, clinical efficacy, safety, and tolerability. Expert Opin Drug Metab Toxicol. 2013;9(2):193-206.

13. Grunder G. Cariprazine, an orally active D2/D3 receptor antagonist, for the potential treatment of schizophrenia, bipolar mania and depression. Curr Opin Investig Drugs. 2010;11(7):823-832.

14. Agai-Csongor E, Domány G, Nógrádi K, et al. Discovery of cariprazine (RGH-188): a novel antipsychotic acting on dopamine D3/D2 receptors. Bioorg Med Chem Lett. 2012;22(10):3437-3440.

15. Kiss B, Horváth A, Némethy Z, et al. Cariprazine (RGH-188), a dopamine $\mathrm{D}(3)$ receptor-preferring, $\mathrm{D}(3) / \mathrm{D}(2)$ dopamine receptor antagonist-partial agonist antipsychotic candidate: in vitro and neurochemical profile. J Pharmacol Exp Ther. 2010;333(1):328-340.

16. Joyce JN, Millan MJ. Dopamine D3 receptor antagonists as therapeutic agents. Drug Discov Today. 2005;10(13):917-925.

17. Tadori Y, Forbes RA, McQuade RD, Kikuchi T. In vitro pharmacology of aripiprazole, its metabolite and experimental dopamine partial agonists at human dopamine D2 and D3 receptors. Eur J Pharmacol. 2011;668(3):355-365.

18. Kiss B, Horti F, Bobok A, et al. Cariprazine, a D3/D2 dopamine receptor partial agonist antipsychotic, displays greater D3 receptor occupancy in vivo compared with other antipsychotics. Biol Psychiatry. 2012; 71(8 Suppl 1):40S.

19. Arranz MJ, de Leon J. Pharmacogenetics and pharmacogenomics of schizophrenia: a review of last decade of research. Mol Psychiatry. 2007;12(8):707-747.

20. Newman-Tancredi A, Kleven MS. Comparative pharmacology of antipsychotics possessing combined dopamine D2 and serotonin 5-HT1A receptor properties. Psychopharmacology (Berl). 2011;216(4): 451-473. 
21. Kiss B, Peterson S, Nemethy Z, Fazekas K, Masri B, Caron M. Effects of cariprazine on D2 and D3 dopamine receptor signalling mechanisms in vitro. Basic and Clin Pharmacol Toxicol. 2010;107 Suppl 1:379.

22. Chiodo LA, Bunney BS. Typical and atypical neuroleptics: differential effects of chronic administration on the activity of A9 and A10 midbrain dopaminergic neurons. J Neurosci. 1983;3(8):1607-1619.

23. White FJ, Wang RY. Differential effects of classical and atypical antipsychotic drugs on A9 and A10 dopamine neurons. Science. 1983;221(4615):1054-1057.

24. Adham-Parangi N, Kiss B, Gyertyan I, et al. RGH-188, a potential antipsychotic with D3/D2 antagonist/partial agonist properties, exhibits an atypical antipsychotic profile in rats with respect to effect on spontaneously active dopamine neurons. Int J Neuropsychopharmacol. 2008;11 Suppl 1:P-07.69. http://dx.doi.org/10.1017/S1461145708009462.

25. Tarazi F, Choi YK, Adham N, Kiss B, Gyertyán I. Effects of chronic exposure of cariprazine on dopamine receptor subtypes. Eur Neuropsychopharmacol. 2012;22 Suppl 2:S349-S350.

26. Tarazi F, Choi YK, Adham N, Kiss B, Gyertyán I. Effects of chronic cariprazine administration on serotonin and glutamate receptor subtypes. Neurpsychopharmacology. 2012;38 Suppl 1:S167.

27. Gyertyán I, Kiss B, Saghy K, et al. Behavioral profile of RGH-188, a novel dopamine D3/D2 antagonist/partial agonist in rodents. Presented at: 36th Annual Meeting of the Society for Neuroscience; October 13-17, 2006; Atlanta, GA.

28. Yasumatsu H, Shiigi Y, Halls BH. Effects of RGH-188, a novel dopamine D3/D2 antagonist/partial agonist, on apomorphine-induced prepulse inhibition deficits and g-butyrolactone-induced increases in dopamine synthesis rate. Presented at: 37th Annual Meeting of the Society for Neuroscience; November 12-16, 2007; San Diego, CA.

29. Adham N, Gyertyán I, Kiss B, et al. Cariprazine shows dopamine D3 receptor-dependent procognitive effects on working memory and social recognition and interaction. Biol Psychiatry. 2011;69(9 Suppl 1): $188 \mathrm{~S}$.

30. Adham N, Gyertyán I, Kiss B, et al. Cariprazine attenuates PCP-induced increases in prefrontal cortical glutamate levels and deficits in cognition and social behaviour. Eur Neuropsychopharmacol. 2012;22 Suppl 2: S347. http://embase.com/search/results?subaction=viewrecord\&rid=5 \&page $=1 \& \mathrm{~L} 70909566$.

31. Carli M, Calcagno E, Mainolfi P, Mainini E, Invernizzi RW. Effects of aripiprazole, olanzapine, and haloperidol in a model of cognitive deficit of schizophrenia in rats: relationship with glutamate release in the medial prefrontal cortex. Psychopharmacology (Berl). 2011;214(3): 639-652.

32. Carli M, Calcagno E, Mainini E, Arnt J, Invernizzi RW. Sertindole restores attentional performance and suppresses glutamate release induced by the NMDA receptor antagonist CPP. Psychopharmacology (Berl). 2011;214(3):625-637.

33. Duman R, Duric V, Banasr M, Adham N, Kiss B, Gyertyán I. Cariprazine exhibits dopamine D3 receptor-dependent antidepressantlike activity in the chronic unpredictable stress model of anhedonia. Neuropsychopharmacology. 2012;38 Suppl 1:S84-S85.

34. Adham N, Gyertyan I, Kiss B, et al. Cariprazine, a D3-preferring dopamine D3/D2 receptor partial agonist, has antidepressant-like activity with fast onset of action in the chronic mild stress-induced anhedonia model. Neuropsychopharmacology. 2010;35 Suppl 1:S171.

35. Peterson S, Masri B, Gao B, et al. Interference with D2 dopamine receptor b-arrestin 2 signaling may relate to the antimanic effects of cariprazine. Biol Psychiatry. 2010;67(9 Suppl 1):234S-235S.

36. Seneca N, Finnema SJ, Laszlovszky I, et al. Occupancy of dopamine $\mathrm{D}_{2}$ and $\mathrm{D}_{3}$ and serotonin 5-HT $\mathrm{A}$ receptors by the novel antipsychotic drug candidate, cariprazine (RGH-188), in monkey brain measured using positron emission tomography. Psychopharmacology (Berl). 2011;218(3):579-587.

37. Caccia S. Pharmacokinetics and metabolism update for some recent antipsychotics. Expert Opin Drug Metab Toxicol. 2011;7(7):829-846.
38. Kirschner N, Gemesi LI, Vastag M. In vitro metabolism of RGH-188. Drug Metab Rev. 2008;40 Suppl 1:128-129.

39. Meszaros GP, Kapas M, Borsos M. Pharmacokinetics of RGH-188, a new dopamine D3/D2 antagonist/partial agonist atypical antipsychotic, in healthy subjects. Eur Neuropsychopharmacol. 2007;217 Suppl 4: S451-S452.

40. Meszaros GP, Agai-Csongor E, Kapas M. Sensitive LC-MS/MS methods for the quantification of RGH-188 and its active metabolites, desmethyl- and didesmethyl-RGH-188 in human plasma and urine. J Pharm Biomed Anal. 2008;48(2):388-397.

41. Tóth M, Varrone A, Steiger C, et al. Brain uptake and distribution of the dopamine D3/D2 receptor partial agonist $[11 \mathrm{C}$ ]cariprazine: an in vivo positron emission tomography study in nonhuman primates. Synapse. 2013;67(5):258-264.

42. Moons T, de Roo M, Claes S, Dom G. Relationship between P-glycoprotein and second-generation antipsychotics. Pharmacogenomics. 2011; 12(8):1193-1211.

43. Citrome L. Cariprazine in schizophrenia: clinical efficacy, tolerability, and place in therapy. Adv Ther. 2013;30(2):114-126.

44. Citrome L. Cariprazine in bipolar disorder: clinical efficacy, tolerability, and place in therapy. Adv Ther. 2013;30(2):102-113.

45. Bose A, Starace A, Wang Q, et al. Cariprazine in the treatment of acute mania in bipolar disorder: a double-blind, placebo-controlled, Phase III trial. Eur Neuropsychopharmacol. 2012;22 Suppl 2:S285.

46. Knesevich M, Papadakis K, Bose A, et al. The efficacy and tolerability of cariprazine in acute mania associated with bipolar I disorder: a Phase II trial. Eur Neuropsychopharmacol. 2009;19 Suppl 3:S469-S470.

47. Laszlovszky I, Bose A, Andor G, et al. The efficacy and tolerability of cariprazine in acute mania associated with bipolar I disorder: a Phase II trial. Int Clin Psychopharmacol. 2011;26 Suppl A:e15.

48. Zukin SR, Kane J, Cutler A, et al. Efficacy and safety of cariprazine in acute exacerbation of schizophrenia: a Phase III, international, randomized double-blind, placebo-controlled trial. Neuropsychopharmacology. 2012;38 Suppl 1:S319.

49. National Institute for Health and Care Excellence. New drug application submitted to FDA for cariprazine for treatment of schizophrenia and manic or mixed episodes associated with bipolar I disorder. Available from: https://www.evidence.nhs.uk/document?ci=http $\% 3 \mathrm{~A} \% 2 \mathrm{~F} \% 2 \mathrm{Fwww}$. businesswire.com $\% 2$ Fportal $\% 2$ Fsite $\% 2$ Fbiospace $\% 2$ Ftemplate PAGE\%2Fmenuitem.ab520ce17e34ab71ff00d635c0908a0c\%2Fin dex.jsp\%3FndmViewId\%3Dnews_view\%26newsId\%3D2012112 7006648\%26newsLang\%3Den\%3Ffromsource\%3Dnelm\&q=car iprazine \&ReturnUrl=\%2Fsearch $\% 3 \mathrm{Fq} \% 3$ Dcariprazine. Accessed July 23, 2013.

50. Forest Laboratories. Forest Laboratories, Inc, and Gedeon Richter Plc. announce results from two positive Phase III trials with the investigational antipsychotic cariprazine for the treatment of schizophrenia [press release]. New York: Forest Laboratories; 2012 [February 28]. Available from: http://news.frx.com/press-release/rd-news/forest-laboratories-incand-gedeon-richter-plc-announce-results-two-positive-p. Accessed July 9, 2013 .

51. Sicard MN, Zai CC, Tiwari AK, et al. Polymorphisms of the HTR2C gene and antipsychotic-induced weight gain: an update and metaanalysis. Pharmacogenomics. 2010;11(11):1561-1571.

52. Rothman RB, Baumann MH, Savage JE, et al. Evidence for possible involvement of 5-HT(2B) receptors in the cardiac valvulopathy associated with fenfluramine and other serotonergic medications. Circulation . 2000;102(23):2836-2841.

53. Buchholz S, Morrow AF, Coleman PL. Atypical antipsychotic-induced diabetes mellitus: an update on epidemiology and postulated mechanisms. Intern Med J. 2008;38(7):602-606.

54. Newcomer JW. Metabolic considerations in the use of antipsychotic medications: a review of recent evidence. J Clin Psychiatry. 2007; 68 Suppl 1:20-27. 
Therapeutics and Clinical Risk Management

Dovepress

\section{Publish your work in this journal}

Therapeutics and Clinical Risk Management is an international, peerreviewed journal of clinical therapeutics and risk management, focusing on concise rapid reporting of clinical studies in all therapeutic areas, outcomes, safety, and programs for the effective, safe, and sustained use of medicines. This journal is indexed on PubMed Central, CAS,

EMBase, Scopus and the Elsevier Bibliographic databases. The manuscript management system is completely online and includes a very quick and fair peer-review system, which is all easy to use. Visit http://www.dovepress.com/testimonials.php to read real quotes from published authors.

Submit your manuscript here: http://www.dovepress.com/therapeutics-and-clinical-risk-management-journal 